\title{
PENANAMAN RELIGIUSITAS KEISLAMAN BERORIENTASI PADA PENDIDIKAN MULTIKULTURAL DI SEKOLAH
}

\author{
A. Suradi \\ (Fakultas Tarbiyah dan Tadris IAIN Bengkulu)
}

\begin{abstract}
Abstrak:
Artikel ini menguraikan tentang bagaimana pendidikan multikultural dalam merespon perubahan demografi dan kultur religius di lingkungan sekolah, bahkan masyarakat secara keseluruhan. Hal ini bertujuan agar dapat tumbuh sikap dan nilai penting bagi harmoni sosial dan perdamaian antar umat beragama. Artikel ini merupakan jenis penelitian pustaka dengan pendekatan deskriptif kualitatif. Ada dua hal yang harus dilakukan untuk mewujudkan pendidikan Islam multikultural, yaitu secara konseptual dan metodologis. Secara konseptual berarti memperkaya diri dengan isu-isu multikulturalisme dari berbagai sumber. Sedangkan secara metodologis, figur pendidik perlu tampil sebagai agen perubahan dalam proses menyemai pemahaman multikulturalisme secara praktis. Dengan demikian, nilainilai pendidikan agama Islam berwawasan multikultural akan berpengaruh signifikan dalam upaya membentuk pola pemahaman keagamaan di kalangan peserta didik baik melalui muatan kurikulum maupun dalam tataran aplikatif dalam proses pembelajaran.
\end{abstract}

Kata Kunci: Religiusitas; Islam; Pendidikan Multikultural; Sekolah. 


\begin{abstract}
:
This article describes how multicultural education responds to demographic changes and religious culture in school environment, and even society as a whole. Thus, it aims to foster attitudes and values which are essential to social life and peace buiding among religious followers. This article is a library research using qualitative descriptive approach. There are two approaches to propose in creating Islamic education with multiculturalism foundation, conceptually and methodologically. The conceptually means to enrich selves with multiculturalism issues from various resources. Next, the methodologically means to promote educating fugure (such as teachers) to act practically in spreading multiculturalism. Therefore, the values of Islamic education with multicultural foundation would significantly support the creation of religious understanding among students through both curriculum contents and learning process.
\end{abstract}

\title{
Keywords: Religiosity; Islam; Multicultural Education; School.
}

\section{A. Pendahuluan}

Pendidikan bertujuan membentuk sikap dan perilaku menuju manusia yang beradab. Sistem pendidikan yang hanya menekankan pada transfer of knowledge, menjadikan pendidikan tidak lagi bermakna dan memberikan efek positif bagi peserta didik. Pedidikan kurang menyentuh sisi humanisme yang pada akhirnya mengembangkan sikap pluralisme sebagai fondasi pemikiran multikulturalisme. Model pendidikan agama seperti ini hanya akan menciptakan peserta didik menjadikan "abdullah" yang hanya saleh secara individual. Paham pluralisme dan multikulturalisme yang saat ini telah menjadi komoditas bidang politik akan terus bergulir dalam ranah pendidikan nasional, termasuk pendidikan agama Islam yang secara integral bagian dari sistem pendidikan nasional. Kebijakan pemerintah tentang pemberlakuan kurikulum 2013 yang meniscayakan penyelenggaraan pendidikan yang berorientasi pada potensi daerah dan nilai-nilai budaya lokal. Kebijakan ini tidak terlepas dari munculnya kesadaran para tokoh dan pemimpin negeri ini bahwa bangsa Indonesia adalah bangsa yang sangat majemuk dan heterogen. Oleh karena itu, tidak mungkin membangun negeri ini tanpa mempedulikan nilai-nilai pluralitas dan multikultural yang terdapat dalam masyarakat.

Undang-undang No. 20 tahun 2003 secara tegas menyatakan bahwa pendidikan agama merupakan bagian yang tak terpisahkan dari sistem pendidikan nasional. Setiap lembaga pendidikan mulai dari tingkat dasar sampai perguruan tinggi wajib memasukkan pendidikan agama sebagai muatan kurikulum. Pasal 37 ayat (1) menjelaskan bahwa pendidikan agama 
dimaksudkan untuk membentuk peserta didik menjadi manusia yang beriman dan bertaqwa kepada Tuhan Yang Maha Esa serta berakhlak mulia. ${ }^{1}$

Pendidikan agama Islam yang dimasukkan dalam kurikulum pendidikan umum mulai dari tingkat dasar sampai perguruan tinggi, merupakan bagian dari pendidikan Islam yang sarat dengan nilai-nilai moral dan spiritual. Pendidikan Islam mempunyai misi esensial untuk membangun karakter muslim yang memahami ajaran agamanya serta mempunyai kesadaran imani yang diwujudkan ke dalam sikap dan perilaku sehari-hari sebagai bentuk pengamalan ajaran agama.

Namun faktanya berbicara lain, pendidikan agama Islam, secara umum belum mampu berkontribusi positif terhadap peningkatan moralitas dan sikap toleransi khususnya di kalangan peserta didik. Hal ini sangat terkait dengan proses implementasinya di lapangan. Dalam praksisnya peserta didik selalu diarahkan pada penguasaan teks-teks yang terdapat dalam buku pengajaran, mereka selalu dihadapkan pada pertanyaan dan hapalan kulit luarnya saja (ranah kognitif), sedangkan substansinya berupa penanaman nilai-nilai agama hilang begitu saja seiring dengan bertumpuknya pengetahuan kognitif mata pelajaran yang ada di sekolah. ${ }^{2}$

Pendidikan Agama Islam yang diajarkan selama ini pada lembagalembaga pendidikan umum mulai dari tingkat SD sampai perguruan tinggi lebih bersifat transfer of knowledge, lebih menekankan kepada pencapaian penguasaan ilmu-ilmu agama. Fragmentasi materi dan terisolasinya atau kurang terkaitnya dengan konteks yang dihadapi dalam kehidupan seharihari yang menyebabkan peserta didik kurang menghayati nilai-nilai agama sebagai nilai yang hidup dalam keseharian.

Konsekuensinya pendidikan agama Islam yang diajarkan menjadi kurang bermakna, kebanyakan peserta didik meningkat pengetahuannya tentang agama, akan tetapi penghayatan dan pengamalan terhadap nilainilai agama terutama yang bersentuhan dengan nilai-nilai humanis dalam bentuk kepedulian sosial misalnya, kurang teraktualisasi dalam kehidupan sehari-hari.Bahkan, tidak jarang pendidikan agama yang membawa kepada kecenderungan sikap dan perilaku peserta didik yang eksklusif dan fanatiks. Sikap eksklusif dan fanatiks inilah yang pada gilirannya melahirkan sikap intoleranasi terhadap perbedaan agama dan sulit menerima perbedaan etnis dan budaya.

Dalam sistem pendidikan agama Islam karena dalam praksisnya pendidikan agama lebih berorientasi pada konsepsi manusia sebagai

\footnotetext{
${ }^{1}$ Undang-Undang RI No. 20 Tahun 2003 Tentang Sistem Pendidikan Nasional.

2 Tujuan PAI selama ini masih terhenti pada ranah kognitif, belum menyentuh ranah afektif dan kepribadian. Lihat Sutrisno, Pembaharuan dan Pengembangan Pendidikan Islam (Yogyakarta: Fadilatama, 2011), 85.
} 


\section{A. Suradi}

"'abdullah" yang lebih menekankan pada pemahaman keagamaan yang dimaknai sebagai ritual dalam bentuk ibadah mahdhah yang hanya melahirkan manusia-manusia yang "saleh" secara individual namun tidak secara sosial. ${ }^{3}$

Walaupun fakta dominan sebenarnya menunjukkan bahwa faktor kesewenangan kelas sosial, kesenjangan ekonomi dan penindasan yang terajut dalam ketidakadilan sosial adalah sumber dan muara konflik, namun sepertinya agama terlanjur ditasbihkan sebagai sumber dan pemicu konflik sosial dan negara. Secara normatif, tidak ada satupun agama yang menganjurkan pemeluknya untuk melakukan tindak kekerasan. Akan tetapi, secara faktual, tidak jarang dijumpai tindak kekerasan yang dilakukan masyarakat "agamis". Bahkan, ada kecenderungan bahwa kekerasan ini justru dilakukan oleh mereka yang mempunyai basic agama yang "kuat" dan melakukannya dengan atas nama agama. Apa yang terjadi di Sulawesi Tengah, Maluku, dan Aceh, juga pemboman dan pembakaran rumah-rumah ibadah agama lain, penyerangan dan pengerusakan terhadap komunitas Ahmadiyah, termasuk pengerusakan atas tempat-tempat hiburan yang dipandang bertentangan dengan norma-norma atau budaya tertentu. ${ }^{4}$

Pendidikan agama berwawasan multikultural itu sendiri merupakan wahana untuk memberikan kesadaran terhadap peserta didik, bahwasanya masyarakat Indonesia adalah masyarakat majemuk. Masyarakat yang memikili keragaman budaya, keyakinan, bahasa, ras, dan suku. Oleh karenanya kemajemukan bangsa ini juga menuntut adanya pendidikan multikultural, dalam rangka mengantisipasi terjadinya konflik tajam diantara perbedaan yang sudah ada. Pendidikan multikultural sebagai pendidikan atau tentang keragaman kebudayaan dalam merespon perubahan demografi dan kultur lingkungan masyarakat tertentu, bahkan dunia secara keseluruhan. Dengan demikian nantinya diharapkan dapat menumbuhkan sikap dan nilai penting bagi harmoni sosial dan perdamaian. ${ }^{5}$

Dalam konteks ini pendidikan agama berwawasan multikultural dipandang sebagai pendidikan progresif dalam melakukan transformasi pendidikan secara komprehensif yang membongkar segala kekurangan dan kegagalan, serta terdapatnya praktek-praktek diskriminatif dalam proses

\footnotetext{
${ }^{3}$ Menurut Munir Mulkhan bentuk-bentuk ritual yang sakral yang selama ini cenderung lebih "memanjakan" Tuhan dan tidak manusiawi, perlu dikembangkan sehingga menjadi ritus-ritus kultural yang sosiologis dan humanis. Lihat: Abdul Munir Mulkhan, Kesalehan Multikultural (Yogyakarta: PSAP Muhammadiyah, 2005), 190.

4 Franz Magnis Suseno, "Memahami Hubungan Antar Agama di Indonesia", dalam Equality and Plurality dalam Konteks Hubungan antar Agama, (Yogyakarta: Sukses Offset, 2008), 7.

5 Azyumardi Azra, Prolog urgensi pendidikan multikultural, Cerita sukses pendidikan multikultural di Indonesia (Jakarta: CRSM Uin Syahid Jakarta, 2010), hlm. XVIII.
} 
pendidikan. ${ }^{6}$ Keragaman budaya, etnik, ras, bahasa, agama merupakan tuntutan bagi pendidikan itu sendiri, sebagai bentuk rasa toleransi dan menjunjung nilai-nilai kemajemukan yang berkembang di negeri ini.

\section{B. Konsep Pendidikan Multikultural}

Dalam bingkai pendidikan, pendidikan multikultural mencoba membantu menyatukan bangsa secara demokratis, dengan menekankan pada perspektif pluralitas masyarakat di berbagai bangsa, etnik, kelompok budaya yang berbeda. Dengan demikian sekolah dikondisikan untuk mencerminkan praktik dari nilai-nilai demokrasi ini. Kurikulum menampakkan aneka kelompok budaya yang berbeda dalam masyarakat, bahasa, dan dialek; dimana para anak didik lebih baik berbicara tentang rasa hormat di antara mereka dan menjunjung tinggi nilai-nilai kerjasama, dari pada membicarakan persaingan dan prasangka di antara sejumlah pelajar yang berbeda dalam hal ras, etnik, budaya dan kelompok status sosialnya.

Pendidikan berbasis multikultural didasarkan pada gagasan filosofis tentang kebebasan, keadilan, kesederajatan dan perlindungan terhadap hakhak manusia. Hakekat pendidikan multikultural mempersiapkan seluruh siswa untuk bekerja secara aktif menuju kesamaan struktur dalam organisasi dan lembaga sekolah. Pendidikan multikultural bukanlah kebijakan yang mengarah pada pelembagaan pendidikan dan pengajaran inklusif dan pengajaran oleh propaganda pluralisme lewat kurikulum yang berperan bagi kompetisi budaya individual.

Adanya konsepsi mengenai pendidikan multikultural, sesungguhnyan tidak terlepas dari kondisi masyarakat Indonesia yang cukup majemuk dan daerah yang berpulau-pulau. Pendidikan multikultural sendiri merupakan konsep dasar dari sebuh perbedaan dalam kehidupan bermasyarakat, sehingga dengan adanya pendidikan multikultural, diyakini mampu memberikan ruang yang seluas-luasnya bagi peserta didik untuk mengembangkan seluruh potensinya, walaupun hal itu dilatar belakangi oleh kondisi yang berbeda.

Dalam Konsepsi H.A.R. Tilaar, pendidikan berwawasan multikultural tidak lepas dari keseluruhan dinamika budaya suatu masyarakat. Oleh sebab itu tinjauan studi kultural haruslah diadakan melalui lintas batas (Border Crossing) yang melangkahi batas-batas pemisah tradisional dari disiplindisiplin dunia akademik yang kaku, sehingga pendidikan multikultural tidak terikat pada horison sempit yang hanya melihat pendidikan di sekolah (School Education) dan proses pendidikan tidak melebihi sebagai proses

\footnotetext{
6 Melani Budianta, Multikulturalisme dan Pendidikan Multikultural : Sebuah Gambaran Umum, dalam Burhanudin (ed). Mencari akar kultural Civiel Society di Indonesia (Jakarta: Indonesia For Institute For Civil Society, 2003), 103.
} 


\section{A. Suradi}

transmisi atau reproduksi ilmu pengetahuan kepada generasi yang akan datang. ${ }^{7}$

Pendidikan dalam wawasan multikultural dalam rumusan James A. Bank adalah konsep, ide atau falsafah sebagai suatu rangkaian kepercayaan dan penjelasan yang mengakui dan menilai pentingnya keragaman budaya dan etnis di dalam membentuk gaya hidup, pengalaman sosial, identitas pribadi, kesempatan-kesempatan pendidikan dari individu, kelompok mapun negara. ${ }^{8}$

Dengan demikian, pendidikan berwawasan multikultur harus melekat dalam kurikulum dan strategi pengajaran, termasuk dalam setiap interaksi yang dilakukan di antara para guru, murid dan keluarga serta keseluruhan suasana belajar mengajar. Jenis pendidikan ini merupakan paedagogi kritis, reflektif dan menjadi basis aksi perubahan dalam masyarakat, maka pendidikan multikultural mengembangkan prinsipprinsip demokrasi dalam berkeadilan sosial. Sementara itu Bikhu Parekh mendefinisikan pendidikan multikultur sebagai "an education in freedom, both in the sense of freedom from ethnocentric prejudices and beases, and freedom to explore and learn from other cultures and perspectives". ${ }^{9}$

James Bank menjelaskan bahwa ada lima dimensi dalam pendidikan berwawasan multikultural, yaitu, pertama, adanya integrasi pendidikan dalam kurikulum (content integration) yang didalamnya melibatkan keragamandalam satu kultur pendidikan yang tujuan utamanya adalah menghapusprasangka. Kedua, konstruksi ilmu pengetahuan (knowledge construction) yang diwujudkan dengan mengetahui dan memahami secara komprehensif keragaman yang ada. Ketiga, pengurangan prasangka (prejudice reduction)yang lahir dari interaksi antar keragaman dalam kultur pendidikan. Keempat,pedogogik kesetaraan manusia (equity pedagogy) yang memberi ruang dankesempatan yang sama kepada setiap elemen yang beragam. Kelima,pemberdayaan kebudayaan sekolah (empowering school culture), yaitu bahwa sekolah adalah elemen pengentas sosial dari struktur masyarakat yangtimpang ke struktur masyarakat yang berkeadilan. ${ }^{10}$

7 H.A.R. Tilaar, Kekuasaan dan Pendidikan, Suatu Tinjauan Dari Perspektif Kultural (Jakarta: Indonesia Tera, 2003), 202.

8 James A. Bank dan Cherry A. Mc Gee (ed), Handbook of research on Multicultural Education (San Francisco: Jossey Bass. 2001), 28. Pendidikan multikultural merupakan proses pendidikan yang komprehensif dan mendasar bagi semua peserta didik. Jenis pendidikan ini menentang segala bentuk rasisme dan segala bentuk diskriminasi di sekolah dan masyarakat dengan menerima dan mengafirmasi pluralitas yang tereflekasikan di antara peserta didik, komunitas mereka dan guru-guru.

9 Bikhu Parekh, Rethinking Multiculturalism: Cultural Diversity and Political Theory (Cambridge: Harvard University Press, 2000), 230.

10 Bank dan Cherry, Handbook of research on Multicultural Education, 23-24. 
Dari uraian di atas, ada hal penting dalam diskursus multikultural dalam pendidikan yaitu identitas, keterbukaan, diversitas budaya dan transformasi sosial. Identitas sebagai salah satu elemen dalam pendidikan mengandaikan bahwa peserta didik dan guru merupakan satu individu atau kelompok yang merepresentasikan satu kultur tertentu dalam masyarakat. Identitas pada dasarnya inhern dalam sikap pribadi atau kelompok masyarakat, dengan identitas nereka berinteraksi, saling mempengaruhi satu sama lain, termasuk interaksi antar budaya yang berbeda. Dalam pendidikan multikultur identitas diasah melalui interaksi budaya internal maupun eksternal. Dengan demikian identitas dan budaya lokal merupakan muatan yang harus ada dalam (kurikulum) pendidikan multikultural.

Lebih jauh lagi pendidikan berwawasan multikultural memiliki perubahan yang drastis, disebabkan oleh pergeseran nilai dan budaya dalam suatu masyarakat. Dengan pendidikan multikultural merupakan bentuk transformasi pengetahuan tidak hanya sebatas di sekolah saja, akan tetapi perubahan dan perkembangan budaya dalam suatu masyarakat menjadi daya tarik tersendiri untuk dianalisis. Perkembangan dan perubahan dalam konteks sosial-budaya, tidak terlepas dari pengetahuan dan pesatnya perkembangan tekhnologi, sehingga dengan mudahnya akses teknologi, menjadikan proses asimilasi antar budaya semakin mempererat hubungan proses kebudayaan dan perubahan itu sendiri.

Sementara itu pendidikan berwawasan multikultural adalah pendidikan yang memperhatikan secara sungguh-sungguh terhadap latar belakang peserta didik baik dari aspek keragaman suku, etnik, ras, budaya, bahasa, dan agama. Konsepsi dari pendidikan multikultural, pada hakekatnya bergerak dari kondisi masyarakat yang cukup beragam. Keberagaman dalam suatu masyarakat adalah bentuk akan kekayaan tradisi yang berkembang di Indonesia, sehingga perbedaan tradisi yang konvensional tersebut dijadikan bahan untuk dilakukan penelitian, sehingga memunculkan pemikiran baru yang bisa diterima didalam masyarakat.

Ide tentang konsep pendidikan berwawasan multikultural menjadi komitmen global sebagaimana yang diungkapkan Sanusi, ada sekurangnya empat pesan dalam rekomendasi UNESCO, yaitu:

1. Pendidikan hendaknya mengembangkan kemampuan untuk mengakui dan menerima nilai-nilai yang ada dalam kebhinnekaan pribadi, jenis kelamin, masyarakat dan budaya serta mengembangkan kemampuan untuk berkomunikasi, berbagi dan bekerjasama dengan yang lain.

2. Pendidikan hendaknya meneguhkan jati diri dan mendorong konvergensi gagasan dan penyelesaian-penyelesaian yang memperkokoh perdamaian, persaudaraan dan solidaritas antara pribadi dan masyarakat.

3. Pendidikan hendaknya meningkatkan kemampuan menyelesaikan konflik secara damai tanpa kekerasan. 


\section{A. Suradi}

4. Pendidikan hendaknya meningkatkan pengembangan kedamaian dalam pikiran peserta didik, sehingga mereka mampu membangaun kualitas toleransi, kesabaran, kemauan untuk berbagi dan memelihara secara lebih kokoh. ${ }^{11}$

James A. Banks ${ }^{12}$ mengidentifikasi ada lima dimensi pendidikan berwawasan multikultural yang diperkirakan dapat membantu guru dalam mengimplementasikan beberapa program yang mampu merespon terhadap perbedaan peserta didik, yaitu:

1. Dimensi integrasi isi/materi (content integration). Dimensi ini digunakan oleh guru untuk memberikan keterangan dengan 'poin kunci' pembelajaran dengan merefleksi materi yang berbeda-beda. Secara khusus, para guru menggabungkan kandungan materi pembelajaran ke dalam kurikulum dengan beberapa cara pandang yang beragam. Salah satu pendekatan umum adalah mengakui kontribusinya, yaitu guru-guru bekerja ke dalam kurikulum mereka dengan membatasi fakta tentang semangat kepahlawanan dari berbagai kelompok. Di samping itu, rancangan pembelajaran dan unit pembelajarannya tidak dirubah. Dengan beberapa pendekatan, guru menambah beberapa unit atau topik secara khusus yang berkaitan dengan materi multikultural.

2. Dimensi konstruksi pengetahuan (knowledge construction). Suatu dimensi dimana para guru membantu siswa untuk memahami beberapa perspektif dan merumuskan kesimpulan yang dipengaruhi oleh disiplin pengetahuan yang mereka miliki. Dimensi ini juga berhubungan dengan pemahaman para pelajar terhadap perubahan pengetahuan yang ada pada diri mereka sendiri;

3. Dimensi pengurangan prasangka (prejudice ruduction). Guru melakukan banyak usaha untuk membantu siswa dalam mengembangkan perilaku positif tentang perbedaan kelompok. Sebagai contoh, ketika anak-anak masuk sekolah dengan perilaku negatif dan memiliki kesalahpahaman terhadap ras atau etnik yang berbeda dan kelompok etnik lainnya, pendidikan dapat membantu siswa mengembangkan perilaku intergroup yang lebih positif, penyediaan kondisi yang mapan dan pasti. Dua kondisi yang dimaksud adalah bahan pembelajaran yang memiliki citra yang positif tentang perbedaan kelompok dan menggunakan bahan pembelajaran tersebut secara konsisten dan terus-menerus. Penelitian menunjukkan bahwa para pelajar yang datang ke sekolah dengan banyak stereotipe, cenderung berperilaku negatif dan banyak melakukan

11 "Pendidikan multikultural dan Implikasinya," A. Effendi Sanusi, terakhir dimodifikasi 2015, hlm. 2, http://blog. unila. ac.id.effendisanusi.

12 James A. Banks, Multicultural Education: Historical Development, Dimensions and Practice, ed. by L. Darling- Hammond, Review of Research in Education, vol. 19, (Washington D.C.: American Educational Research Association, 1993). 
kesalahpahaman terhadap kelompok etnik dan ras dari luar kelompoknya. Penelitian juga menunjukkan bahwa penggunaan teksbook multikultural atau bahan pengajaran lain dan strategi pembelajaran yang kooperatif dapat membantu para pelajar untuk mengembangkan perilaku dan persepsi terhadap ras yang lebih positif. Jenis strategi dan bahan dapat menghasilkan pilihan para pelajar untuk lebih bersahabat dengan ras luar, etnik dan kelompok budaya lain.

4. Dimensi pendidikan yang sama/adil (equitable pedagogy). Dimensi ini memperhatikan cara-cara dalam mengubah fasilitas pembelajaran sehingga mempermudah pencapaian hasil belajar pada sejumlah siswa dari berbagai kelompok. Strategi dan aktivitas belajar yang dapat digunakan sebagai upaya memperlakukan pendidikan secara adil, antara lain dengan bentuk kerjasama (cooperatve learning), dan bukan dengan cara-cara yang kompetitif (competition learning). Dimensi ini juga menyangkut pendidikan yang dirancang untuk membentuk lingkungan sekolah, menjadi banyak jenis kelompok, termasuk kelompok etnik, wanita, dan para pelajar dengan kebutuhan khusus yang akan memberikan pengalaman pendidikan persamaan hak dan persamaan memperoleh kesempatan belajar.

5. Dimensi pemberdayaan budaya sekolah dan struktur sosial (empowering school culture and social structure). Dimensi ini penting dalam memperdayakan budaya siswa yang dibawa ke sekolah yang berasal dari kelompok yang berbeda. Di samping itu, dapat digunakan untuk menyusun struktur sosial (sekolah) yang memanfaatkan potensi budaya siswa yang beranekaragam sebagai karakteristik struktur sekolah setempat, misalnya berkaitan dengan praktik kelompok, iklim sosial, latihan-latihan, partisipasi ekstra kurikuler dan penghargaan staff dalam merespon berbagai perbedaan yang ada di sekolah.

Sistem yang digunakan dalam pendidikan yang ada dinegara ini masih bersifat banking dan tidak mampu memberikan ruang yang seluasluasnya bagi kreatifitas peserta didik untuk mengekplorasi potensinya secara totalitas, sehingga hal ini menjadi PR kita bersama untuk menjadikan pendidikan kita lebih bermutu, lebih bermartabat, dan mampu menjadi harapan bagi masyarakat luas. ${ }^{13}$ Prinsip dari pendidikan multikultural itu sendiri, melihat seluruh aspek secara komprehensif, mulai dari sistem pendidikan, visi dan misi, latar belakang peserta didik, serta perubahan dan perkembangan tradisi yang melingkupi pendidikan itu sendiri, sehingga dari situlah akan selalu muncul evaluasi dan introspeksi dari pergerakan

13 Faisol, Gus Dur dan Pendidikan Islam, Upaya Mengembalikan Esensi Pendidikan di era Global (Jogjakarta: Ar-Ruzz Media, 2011), 14. 


\section{A. Suradi}

pendidikan, menuju kualitas pendidikan yang menjadi harapan masyarakat luas.

Dengan demikian multikultural dalam prakteknya merupakan pemberian kebebasan untuk menjalankan dan memenuhi segala keuikan masing-masing budaya yang ada. Terjamin secara legal oleh Undang-undang dan secara moral-cultural diakui oleh masyarakat. Tanpa adanya toleransi dan keterjaminan berekspresi, niscaya tidak akan ada multikulturalisme dalam praktek kemasyarakatan secara kongkret.

\section{Tujuan Penanaman Religiusitas Keislaman Berwawasan Multikultural}

Pendidikan agama Islam di era modern menjadi sebuah gambaran, akan pentingnya perubahan, melirik terhadap perkembangan pengetahuan dan tekhnologi, sebab dua hal tersebut, sudah menjadi keharusan, baik bagi pemerintah, pendidik, dan masyarakat (stakeholder) untuk bersama-sama menjadikan modernisasi sebagai salah satu bentuk yang menuntut terhadap kemajuan dalam pendidikan itu sendiri. Karena pada hakekatnya modernisasi itu sendiri, dipandang sebagai sebuah upaya implementasi pemikiran dalam konstek pendidikan agama yang lebih maju.

Pendidikan agama Islam telah mengantarkan peserta didik, pada kemajuan berpikir, kematangan sikap, serta berupaya membentuk akhlaq mulia. Dengan pendidikan pula proses transformasi pengetahuan dan penerapan tekhnologi yang telah diajarkan selama proses belajar mengajar, telah menjadikan pendidikan sebagai ujung tombak dari perubahan itu sendiri, disamping itu pula pendidikan telah menjadikan sebuah budaya ikut berkembang sesuai dengan tuntutan zaman. Sesungguhnya budaya adalah model dari ilmu pengetahuan manusia, kepercayaan dan pola tingkah laku yang satu, budaya kemudian dilihat dari aspek-aspek dari segi bahasa, ide, keyakinan, adat-istiadat, kode moral, institusi, tekhnologi, seni ritual, upacara-upacara dan komponen-komponen lainnya yang saling berkaitan. Perkembangan budaya tergantung terhadap kapasitas manusia untuk terus mempelajari budaya itu dan mentranformasikan ilmu pengetahuan mereka kepada generasi berikutnya. ${ }^{14}$

Oleh karenanya perkembangan dan perubahan dari suatu budaya pada era modernitas ini, akan selalu berkaitan dengan pendidikan. Pendidikan sebagai wahana proses transformasi pengetahuan terhadap peserta didik akan menjadikan kapasitas SDM lebih maju dan berkembang. Pendidikan itu sendiri akan selalu bergesekan dengan budaya global, dimana asimilasi budaya kerapkali mewarnai corak pendidikan Islam.

14 Amer Al Roubaie, "Globalisasi dan Posisi Peradaban Islam," Islamia, (Jakarta: diterbitkan oleh Institute for the Study of Islamic Thought and Civilization (INSISTS) dan Khairul Bayan, 2005), 13. 
Dalam konstek budaya, ada dua hal besar yang saling mempengaruhi, yakni budaya tidur dan juga budaya barat. Satu sisi budaya barat telah mempengaruhi budaya ketimuran, namun pada sisi yang lain berkembangnya dan dilestarikannya budaya ketimuran juga memiliki pengaruh yang kuat terhadap perkembangan budaya barat.

Dengan pesatnya pengetahuan dan tekhnologi, maka seakan kedua budaya tersebut saling berbaur satu sama lain, sebab dengan canggihnya tekhnologi seakan dunia sudah tanpa ada batas. Keduanya seakan telah melebur yang kemudian memberikan corak warna tersendiri. Akan tetapi perlu untuk digaris bawahi, bahwasanya adat ketimuran masih memiliki nilai-nilai yang kental dan syarat akan patuhnya terhadap agama dan keyakinan, sebagai sumber dan pedoman dalam menjalankan kehidupan. Nilai-nilai agama dan keyakinan dalam tradisi ketimuran, masih dipegang teguh oleh para penganutnya, sehingga masuknya westernisasi, khususnya dalam kalangan kaum muda, sedikit banyak masih mampu ditanggulangi, walaupun ada sebagian yang sudah menganut budaya kebarat-baratan.

Dengan demikian pendidikan Islam di era modern merupakan wahana untuk menjadi kontrol yang kuat terhadap peserta didik, dengan cara mengajarkan nilai-nilai ketimuran yang baik, dan mengambil nilai-nilai budaya barat yang lebih baik, sehingga sistem dari sebuah pendidikan menjadi harapan bagi seluruh lapisan masyarakat, guna menuntun para peserta didik untuk memiliki kecerdasan intelektual, emosional dan spritual. Integrasi nilai inilah yang harus ditanamkan terhadap peserta didik dalam rangka mengembangkan dan mengarahkan seluruh potensinya, menjadi keharusan bagi tenaga kependidikan, sehingga tercipta keseimbangan dan keharmonisan antara kepentingan duniawi dan ukhrowi.

Konsep pendidikan agama Islam berwawasan multikultural mengulas berbagai permasalahan pendidikan agama islam yang mendukung ideologi, politik, demokrasi, keadilan, penegakan hukum, kesempatan kerja dan usaha, hak asasi manusia, hak budaya komuniti dan golongan minoritas, prinsip-prinsip etika dan moral, tingkat dan mutu produktivitas serta berbagai konsep lainnya yang lebih relevan. Dengan ungkapan lebih sederhana, sebuah penilaian pendidikan agama Islam terhadap kebudayaankebudayaan orang lain, bukan dalam arti menyetujui seluruh aspek dari kebudayaan-kebudayaan tersebut, melainkan mencoba melihat bagaimana kebudayaan tertentu dapat mengekspresikan nilai bagi anggota-anggotanya sendiri.

Tujuan pendidikan agama Islamberwawasanmultikultural adalah mengubah pendekatan pelajaran dan pembelajaran agama Islam ke arah memberikan peluang yang sama pada setiap anak. Siswa ditanamkan pemikiran lateral, keanekaragaman, dan keunikan itu dihargai. Hal ini 


\section{A. Suradi}

berarti harus adaperubahan sikap, perilaku dan nilai-nilai khususnya civitas akademika sekolah. Ketika siswa berada di antara sesamanya yang berlatar belakang berbeda, mereka harus belajar satu sama lain, berinteraksi dan berkomunikasi sehingga dapat menerima perbedaan diantara mereka sebagai sesuatu yang memperkaya mereka.Tujuan pendidikan agama Islam berwawasan multikultural adalah untuk membantu siswa Memahami latarbelakang diri dan kelompok dalam masyarakat; Menghormati dan mengapresiasi ke-bhineka-an budaya dan sosio-historis etnik; Menyelesaikan sikap-sikap yang terlalu etnosentris dan penuh purbasangka; Memahami faktor-faktor sosial, ekonomis, psikologis dan historis yang menyebabkanterjadinya polarisasi etnik ketimpangan dan keterasingan etnik; Meningkatkan kemampuan menganalisas secara kritis masalahmasalah rutin dan isu melalui proses demokratis melalui sebuah visi tentang masyarakat yang lebih baik, adil dan bebas; Mengembangkan jati diri yang bermakna bagi semua orang.

Dengan demikian, nilai-nilai inti dari pendidikan agama Islam berwawasan multikultural berupa demokratis, humanisme dan pluralisme. Nilai demokratisasi atau keadilan merupakan istilah bahwa setiap insan mendapatkan sesuatu yang dibutuhkan, bukan yang diinginkan. Nilai humanisme atau kemanusiaan manusia pada dasarnya adalah pengakuan akan adanya keragaman yang berupa ideologi, agama, paradigma, suku bangsa, pola pikir, kebutuhan, tingkat ekonomi dan sebagainya. Sedangkan nilai pluralisme adalah pandangan yang mengakui adanya keragaman suatu bangsa, berkenaan dengan hak hidupkelompok-kelompok masyarakat yang ada dalam suatu komunitas.

Nilai-nilai pendidikan agama Islamberwawasan multikultural berpengaruh signifikan dalam upaya membentuk pola pemahaman keagamaan di kalangan peserta didik. Nilai- nilai tersebut tidak hanya tertuang dalam muatan kurikulum pendidikan agama Islam, namun juga tercermin dari pemahaman guru yang diaplikasikan dengan pendekatan dan metode yang digunakan dalam proses pendidikan agama Islam. Pandangan dan pemahaman yang positif bagi guru agama terhadap paham pluralisme dan multikulturalisme pada gilirannya akan mampu mentransformasikan pola pemahaman Indikasi kegagalan tersebut tidak terlepas dari peranan guru pendidikan agama dalam memberikan pemahaman keagamaan kepada peserta didik.

Ada sinyalemen bahwa pemahaman keagamaan yang dibangun selama ini melalui pendidikan agama berangkat dari suatu pandangan yang memposisikan "agama" sebagai sebuah ajaran yang bersifat absulut, statis dan baku. Konsekwensinya pemahaman dan pandangan terhadap paham multikulturalisme hanyalah sebatas pada tatanan wacana pemikiran kajian 
keislaman, bahkan lebih ekstrim, muncul kecenderungan memaknainya sebagai sebuah propaganda Barat dalam upaya menyerang dan menghapus tradisi-tradisi Nabi dan Sahabat yang selama ini secara konsisten dilestarikan oleh kelompok Islam fundamentalis.

Keberadaan pendidikan agama Islam berwawasan multikultural yang dikembangkan sesuai dengan nilai-nilai Islam serta dinamika masyarakat modern, sesungguhnya sangat tepat untuk menjawab sekian banyak persoalan yang menyangkut dimensi perbedaan dan keragaman. Perkembangan kehidupan manusia yang semakin cepat tanpa dibatasi oleh ruang dan waktu, sangat memerlukan sebuah kesadaran individu yang kemudian berimplikasi pada kesadaran kolektif untuk menerima dan menempatkan segala perbedaan dan keragaman tersebut sebagai bagian yang perlu dihargai dan dihormati.

Berangkat dari konsep yang demikian, maka sudah seharusnya nilainilai multikulturalisme dapat terintegrasi secara jelas dalam agenda pendidikan agama Islam. Adapun pendidikan Islam, dalam pengertian yang bersifat normatif merupakan suatu proses spiritual, akhlak, intelektual dan sosial untuk membimbing manusia sekaligus memberikan kepada mereka nilai-nilai, prinsip-prinsip dan teladan ideal dalam kehidupan, dengan tujuan untuk memperoleh kebahagiaan hidup dunia dan akhirat. Semangat dan nilai-nilai multikulturalisme yang terintegrasi dalam sistem dan aktivitas pendidikan Islam, merupakan suatu upaya untuk mengakomodasi dan menata dinamika keragaman, perbedaan dan kemanusiaan melalui aktivitas pendidikan. Dengan demikian, pendidikan Islam multikultural pada hakikatnya adalah pendidikan yang menempatkan multikultural sebagai salah satu visi pendidikan dengan karakter utama yang bersifat inklusif, egaliter dan humanis, namun tetap kokoh pada nilai-nilai spiritual dan ketuhanan yang berdasarkan al-Qur'an dan as-Sunnah.

\section{Orientasi Multikultural dalam Penanaman Religiusitas Keislaman}

Secara konseptual-normatif, pendidikan agama Islam yang terdapat pada lembaga-lembaga pendidikan umum dimaksudkan sebagai upaya dalam membangun dan menumbuhkan sikap kebhinekaan berupa toleransi terhadap perbedaan etnik, budaya dan agama di kalangan peserta didik. Meskipun sebenarnya hal ini bukan semata tanggung jawab pendidikan agama Islam, namun pendidikan agama Islam memiliki peran yang signifikan dalam membangun dan menanamkan sikap toleransi serta 


\section{A. Suradi}

kesadaran menerima perbedaan etnik, budaya dan agama di kalangan peserta didik. ${ }^{15}$

Namun realitanya, banyak kalangan yang menilai kegagalan pendidikan agama Islam dalam membangun dan menumbuhkan sikap toleransi dan kesadaran menerima perbedaan etnis, budaya dan agama yang sesungguhnya bersifat manusiawi (humanis). Sikap kritis tersebut telah memunculkan wacana dan gagasan tentang perlunya memasukkan nilainilai pluralisme dan multikulturalisme dalam pendidikan agama Islam. Meskipun hampir semua masyarakat yang berbudaya kini sudah mengakui dan menerima adanya kemajemukan sosial, budaya dan agama, namun dalam kenyataannya, permasalahan toleransi ini masih sering muncul dalam suatu masyarakat. ${ }^{16}$

Persoalan-persoalan yang muncul tersebut di atas, setidaknya dapat dilihat dari dua aspek, yakni: Pertama, aspek kuantitatif, pendidikan Islam multikultural masih belum tersosialisasi dengan baik dan belum berpengaruh luas terhadap masyarakat, terutama di lingkungan pendidikan. Walaupun di tingkat perguruan tinggi wacana multikultural sudah cukup mendapat tempat, namun di tingkat sekolah (menengah) khususnya yang berada di daerah, sekolah umum, madrasah maupun pesantren, spirit dan nilai-nilai multikultural belum tersosialisasi secara luas. Begitupun dengan pemahaman masyarakat terkait pentingnya multikulturalisme, secara umum dapat dikatakan masih sangat sempit. Kedua, aspek kualitatif, baik dari sisi konsep maupun implementasinya masih banyak bagian yang perlu dibenahi. Secara konsep, pendidikan Islam multikultural kurang tersistematisasi dengan baik, terutama untuk dijadikan dasar dalam pelaksanaannya di lapangan. Hal ini dapat dilihat dari minimnya referensi hasil pemikiran yang secara rinci menjelaskan bentuk-bentuk implementasi pendidikan Islam multikultural, sehingga berdampak pada usaha-usaha praktis yang akan dilakukan. Begitupula dalam proses pembelajaran terutama di tingkat sekolah menengah, multikulturalisme belum terintegrasi secara jelas di dalam kurikulum, baik sebagai materi tersendiri, pokok bahasan atau materi sisipan. Kondisi ini ditambah pula dengan persoalan tenaga pendidik yang sebagian besar belum memahami dengan baik mengenai konsep

${ }^{15}$ Max Weber meyakini bahwa agama memiliki kekuatan untuk mempengaruhi manusia dengan segala variasinya dari masyarakat sederhana sampai masyarakat maju sekalipun. Lihat Max Weber, Sosiologi Agama (Yogyakarta: IRCiSoD, 2002), 1-28.

${ }^{16}$ Nur Ahmad, ed., Pluralitas Agama Kerukunan dalam Keragaman, (Jakarta: Kompas, 2001), 21. 
multikulturalisme yang berimplikasi pada proses internalisasi dalam pembelajaran. ${ }^{17}$

Surat Al-Hujurat ayat 13 memberikan orientasi dari pendidikan multikultural Islam ialah tertanamnya sikap simpati, respek, apresiasi (menghargai), dan empati terhadap penganut agama dan budaya yang berbeda untuk meningkatkan kadar taqwa kita di sisi Allah. Allah tidak melihat darimana ia berasal, seberapa tampan atau cantik, seberapa kaya, seberapa tinggi pangkat/jabatan, seberapa kuat badannya, tapi yang dilihat Allah ialah seberapa besar tingkat taqwanya.

Pendidikan agama Islam berwawasan multikultural, sebagai pendidikan yang bergenre "pembebasan", pendidikan multikultural mulairamai dibicarakan dan diwacanakan di Indonesia. Kehadirannya diharapkan menjadi solusi sekaligus alternatif pendidikan yang bisa menjadi pencegah dari perpecahan dan disintegrasibangsa Indonesia yang majemuk. Kehadirannya merupakan sebuah idealisme bangsa yangberkali-kali terjangkit perpecahan, pertikaian etnis, perang saudara dan tragedi kemanusiaan berisu SARA, atau kekerasan-kekarasan lain yang disebabkan kekurangan pemahaman tentangfakta keberagaman. Lantas bagaimana konsep pendidikan mutikultural diintegrasikan dalam sistem pendidikan di Indonesia, khususnya dalam pendidikan agama Islam?

Amin Abdullah dalam sebuah penelitiannya mengatakan bahwa guru-guru agama di sekolah yang berperan sebagai ujung tombak pendidikan agama dari tingkat yang paling bawah hingga yang paling tinggi nyaris kurang tersentuh oleh gelombang pergumulan pemikiran dan diskursus pemikiran keagamaan diseputar isu pluralisme dan multikulturalisme.18 Pada hal guru-guru inilah yang menjadi mediator pertama untuk menterjemahkan nilai-nilai pluralisme dan multikulturalisme kepada peserta didik, yang pada tahap selanjutnya juga ikut berperan aktif dalam mentransformasikan kesadaran toleransi secara lebih intensif dan massif.

Dominasi dan orientasi pemahaman bayani yang berlebihan menimbulkan persoalan dalam pemikiran hukum Islam, apatah lagi dalam konteks globalisasi sekarang ini yang dapat membawa pada kecenderungan

\footnotetext{
17 Muhammad Fathurrohman, "Pendidikan Islam Multikultural (Menggagas Transformasi Pendidikan Islam yang Multikultural)," Muhammad Fathurrohman Blog, 4 Oktober 2012, https://muhfathurrohman.wordpress.com/2012/10/04/pendidikan-islammultikultural/

18 M. Amin Abdullah, "Agama dan (Dis) Integrasi Sosial: Tinjauan Materi dan Metodologi Pembelajaran Agama (Kalam dan Teologi) dalam Era Kemajemukan di Indonesia", (Makalah disampaikan dalam Seminar Panitia Ad Hoc BPMPR RI tentang Perubahan Kedua UUD 1945 dalam Perspektif Hukum, Sub Topik Agama dan Budaya, Mataram, 22 s.d 23 Maret 2003).
} 


\section{A. Suradi}

eksklusivisme dan truth-claim. Menurut Amin Abdullah, pola pikir yang tekstual-bayani telah membentuk mainstream pemikiran keislaman yang hegemonik dan itu sudah berlangsung selama ini. Dominasi pola pikir tekstual-ijtihadiyyah menjadikan sistem epistimologi kajian keislaman kurang responsif terhadap isu-isu keagamaan yang bersifat kekinian (kontekstual-bahsiyyah). ${ }^{19}$

Ada dua hal yang harus dilakukan untuk mewujudkan pendidikan Islam multikultural. Kedua hal ini bersipat konseptual dan metodologis, yang nanti bisa dikembangkan dan diturunkan menjadi langkah-langkah praktis, yaitu: Pertama, birokrat pendidikan, guru, dan siswa harus mampu mengakses informasi tentang isu-isu multikultural, baik dari media massa maupun lewat forum diskusi, sehingga mereka tumbuh menjadi seorang figur multikultural. Mereka harus aktif membaca buku dan mengikuti perkembangan informasi lewat media massa. Ketika birokrat pendidikan menjadi seorang figur multikultural, maka kebijakan pendidikan, termasuk produk hukum pun akan mendukung multikultural. Begitupun guru dan siswa. Ketika mereka tumbuh menjadi figur multikultural, maka proses pengaran dan pembelajaran pun akan memuat nilai-nilai multikultural. Kedua, kegiatan multikultural adalah bagian dari nilai spiritual. Oleh karena itu, siswa harus diberikan penjelasan tentang nilai-nilai spiritual dari kegiatan yang mereka lakukan tersebut. Sehingga setiap saat mereka akan dihadapkan pada kesadaran spiritual. Sebagai contoh guru mengajak diskusi tentang pentingnya membersihkan lingkungan, menghormati orang yang berbeda agama. Guru mengajak siswa menonton film atau acara-acara televisi yang memuat wawasan dan nilai-nilai kemanusiaan. Ia menjelaskan bahwa ketiga hal tersebut merupakan. bagian dari nilai-nilai multikultural dan refleksi dari ibadah kepada Tuhan. ${ }^{20}$

Berdasarkan argumentasi di atas, agaknya di sinilah letak problematika yang mendasar dalam sistem pendidikan agama Islam yang cenderung mengabaikan nilai-nilai humanisme yang plural dan multikultural disebabkan paradigma tekstual-literal yang mendominasi sebagai landasan berpikir di kalangan guru-guru agama Islam. Untuk lebih jelasnya, kiranya persoalan ini dipelukan suatu kajian mendalam melalui suatu formulasi kerangka penelitian, sehingga benar-benar akan menghasilkan sesuatu yang kontributif terhadap peningkatan mutu dan kualitas pendidikan agama Islam.Dengan demikian tidak akan ada keraguan bagi kita para pendidik Islam untuk mengimplementasikan wawasan

19 M. Amin Abdullah, Mazhab Yogya: Menggagas Paradigma Ushul Fiqh Kontemporer, (Yogyakarta: Arruz Press, 2002), 118.

20 Azyumardi Azra, Pendidikan Islam: Tradisi dan Modernisasi Menuju Milenium Baru, (Jakarta: Logos Wacana Ilmu, 2000), 291. 
multikultural dalam pendidikan yang kita lakukan. Dengan pendidikan multikultural Islam akan semakin inklusif tidak eksklusif, membumi tidak melangit, kontekstual tidak tekstual, dan betul-betul merupakan bagian dari perwujudan Islam sebagai rahmatan lil a'lamin.

Pengembangan faham multikultural dalam sistem pendidikan agama Islam tidak akan pernah terbentuk dengan sendirinya. Dibutuhkan proses yang panjang dan sistematis. Paham multikultural sebagai entitas yang paling asasi dalam sistem pendidikan agama Islam ini harus tertanam semenjak dini, dan salah satu lembaga yang tepat untuk menanamkan dan mengembangkannya adalah lembaga pendidikan Islam, melalui kurikulum pendidikan Islam yang akomodatif terhadap kepentingan ini. Dalam konteks ini, tentu saja pengajaran agama Islam yang diajarkan di sekolah-sekolah harus memuat kurikulum berbasis keanekaragaman (multikultur). Pendidikan agama Islam diberikan kepada siswa tidak dalam bentuk kurikulum yang tunggal, melainkan kurikulum pendidikan yang dapat menunjang proses siswa menjadi manusia yang demokratis, pluralis dan menekankan penghayatan hidup serta refleksi untuk menjadi manusia yang utuh.

\section{E. Penutup}

Cita-cita pendidikan agama berwawasan multikultural semakin jauh karena dalam konteks nasional, Indonesia telah banyak dipengaruhi globalisasi yang menghasilkan sebuah corporate capitalism yang telah memonopoli pendidikan yang pada dasarnya adalah hak setiap manusia. Dengan hal tersebut, konsep pendidikan multikultural akan mengurangi kerentanan Bangsa Indonesia terhadap potensi konflik di kalangan remaja. Pendidikan agama berwawasan multikultural juga ditunjukkan pada keadilan sosial, mengurangi kesenjangan sosial yang diakibatkan oleh caracara pembangunan yang salah selama ini. Selain itu konsep pendidikan agama berwawasan multikultural juga dapat dikatakan dengan pendidikan yang membebaskan. Selama ini pendidikan agama yang dijalan di Indonesia adalah konsep pendidikan yang mengekang, hagemoni dan dominasi melekat dalam pendidikan Islam yang normatif. Terdidik seperti sebuah robot, selama ini generasi penerus bangsa dipaksa untuk menelan mentahmentah informasi-informasi tanpa boleh membantah dan menyangkalnya. Seperti halnya perilaku orde baru yang menggunakan pendidikan untuk melanggengkan kekuasaannya. Fakta-fakta itu menegaskan hegemoni negara dalam kebijakan dan praktik pendidikan menjadi konteks jitu yang mengasah counter dis course bagi visi pendidikan penguasa.

Pengembangan nilai-nilai pendidikan agama Islam yang berwawasan multikultural berpengaruh dalam membentuk pola pemahaman keagamaan 


\section{A. Suradi}

di kalangan peserta didik. Nilai-nilai tersebut tidak hanya tertuang dalam muatan kurikulum pendidikan agama Islam, namun juga tercermin dari pemahaman guru yang diaplikasikan dengan pendekatan dan metode yang digunakan dalam proses pendidikan agama Islam. Pandangan dan pemahaman yang positif bagi guru agama terhadap paham pluralisme dan multikulturalisme pada gilirannya akan mampu mentransformasikan pola pemahaman.

\section{F. Referensi}

Abdullah, M. Amin. Agama dan (Dis) Integrasi Sosial: Tinjauan Materi dan Metodologi Pembelajaran Agama (Kalam dan Teologi) dalam Era Kemajemukan di Indonesia." Seminar Panitia Ad Hoc BPMPR RI tentang Perubahan Kedua UUD 1945 dalam Perspektif Hukum. Mataram, 2003.

-. Mazhab Yogya: Menggagas Paradigma Ushul Fiqh Kontemporer. Yogyakarta: Arruz Press, 2002.

Ahmad, Nur. Pluralitas Agama Kerukunan dalam Keragaman. Jakarta: Kompas, 2001.

Azra, Azyumardi. Cerita sukses pendidikan multikultural di Indonesia. Jakarta: CRSM UIN Syahid Jakarta, 2010.

-. Pendidikan Islam: Tradisi dan Modernisasi Menuju Milenium Baru. Jakarta: Logos Wacana Ilmu, 2000.

Banks, James A. Multicultural Education: Historical Development, Dimensions and Practice. Washington D.C.: American Educational Research Association, 1993.

Budianta, Melani. Mencari akar kultural Civiel Society di Indonesia. Jakarta: Indonesia For Institute For Civil Society, 2003.

Faisol. Gus Dur dan Pendidikan Islam, Upaya Mengembalikan Esensi Pendidikan di era Global. Jogjakarta: Ar-Ruzz Media, 2011.

Fathurrohman, Muhammad. "Pendidikan Islam Multikultural (Menggagas Transformasi Pendidikan Islam yang Multikultural)." Muhammad Fathurrohman Blog. Oktober $\quad 4, \quad 2012$. https://muhfathurrohman.wordpress.com/2012/10/04/pendidikanislam-multikultural/.

Gee, James A. Bank dan Cherry A. Mc. Handbook of research on Multicultural Education. San Francisco: Jossey Bass, 2001. 
Mulkhan, Abdul Munir. Kesalehan Multikultural. Yogyakarta: PSAP Muhammadiyah, 2005.

Parekh, Bikhu. Rethinking Multiculturalism: Cultural Diversity and Political Theory. Cambridge: Harvard University Press, 2000.

Roubaie, Amer Al. "Globalisasi dan Posisi Peradaban Islam." Islamia, 2005: 13.

Sanusi, A. Effendi. "Pendidikan multikultural dan Implikasinya," . http://blog. unila. ac.id.effendisanusi.

Suseno, Franz Magnis. Equality and Plurality dalam Konteks Hubungan antar Agama. Yogyakarta: Sukses Offset, 2008.

Sutrisno. Pembaharuan dan Pengembangan Pendidikan Islam. Yogyakarta: Fadilatama, 2011.

Tilaar, H.A.R. Kekuasaan dan Pendidikan, Suatu Tinjauan Dari Perspektif Kultural. Jakarta: Indonesia Tera, 2003.

Weber, Max. Sosiologi Agama. Yogyakarta: IRCiSoD, 2002. 